\title{
Mastitis control in Swedish dairy herds
}

\author{
C. Nielsen ${ }^{1}$ and U. Emanuelson \\ Swedish University of Agricultural Sciences, Department of Clinical Sciences, Division of Ruminant Medicine and Epidemiology, PO Box 7054, \\ SE-75007 Uppsala, Sweden
}

\section{ABSTRACT}

The aim of this study was to investigate which preventive measures targeting mastitis are implemented in Swedish dairy herds with different housing and milking systems. Data were collected through a selfadministered postal questionnaire sent to 898 dairy farmers, stratified by housing and milking system, in May 2011. The questionnaire contained general questions about the herd and the person responsible for the udder health of the cows, and specific questions about perceived udder health and the implementation of preventive measures. The response rate was $48 \%$. The median herd size of participating herds was 80 cows, and the median herd average milk yield per cow was 9,586 $\mathrm{kg}$ of milk. External validity was assessed by comparing participating herds with nonresponders in respect to key performance indicators in the Swedish official milk recording system; no significant differences were found. When herds with combined systems had been removed, 400 herds with tiestalls and pipeline milking, freestalls and parlor milking, and freestalls with an automatic milking system remained. Differences between herd types were analyzed using the Kruskal-Wallis test and Fisher's exact test. The results showed that herd types differed in their rates of implementation of different preventive measures. Freestall herds with milking parlors implemented more preventive measures related to milking hygiene and milking routines than did tiestall herds. A milking order based on the udder health status of the cows was frequently implemented in tiestall herds, but not in most herds with an automatic milking system or most freestall herds with milking parlors. Irrespective of herd type, the proportion of herds in which cows were kept standing for at least $30 \mathrm{~min}$ after milking was low. A substantial proportion of herds ignored the udder health status of lactating cows when grouping them, and few herds grouped dry cows according to udder health status, although this occurred more frequently in tiestall herds. A large proportion of

Received August 3, 2012.

Accepted August 9, 2013.

${ }^{1}$ Corresponding author: christel.nielsen@slu.se herds, especially those with tiestalls, did not allow cows and heifers to calve in single pens that were cleaned between animal occupations. These findings can be used to tailor advice on mastitis specifically to different herd types and thus improve the efficiency of mastitis control.

Key words: dairy herd, mastitis control, preventive measure

\section{INTRODUCTION}

Mastitis remains a major issue in dairy production, despite the fact that control programs have been available and implemented since the 1960s. In Sweden, in 2010, the lactational incidence of veterinary-diagnosed clinical mastitis in herds participating in the Swedish official milk-recording scheme (SOMRS) was $17.3 \%$ (Swedish Dairy Association, 2011). The true incidence is probably substantially higher, because there is considerable underreporting (Mörk et al., 2009). Furthermore, calculations indicate that two-thirds of Swedish cows suffer from subclinical mastitis annually (Swedish Dairy Association, 2006). In 1990, the lactational incidence of veterinary-diagnosed clinical mastitis in herds participating in SOMRS was 18.3\% (Swedish Dairy Association, 1991). Thus, the incidence has not changed significantly over the last 2 decades.

Two explanations for this can be proposed. First, an unfavorable genetic correlation exists between udder health and milk yield (Heringstad et al., 2000). Selection only for increased production, which has traditionally been pursued in many countries, results in deteriorating udder health. However, in the Nordic countries, a broader breeding goal, including functional traits such as mastitis resistance, has been adopted since the mid-1980s, yet udder health has still not improved. It is worth noting, however, that the genetic trend for clinical mastitis in the Nordic Red breeds has been stable (Johansson et al., 2006), despite an increase in the average yield of Swedish Red cows of almost 2,000 $\mathrm{kg}$ in the period from 1990 to 2010 (Swedish Dairy Association, 2011). The stable genetic trend suggests that there was room to improve udder health through management changes. The fact that no improvement has occurred indicates that the implemented control 
program has not achieved its desired effects. Certainly, that possibility would provide a second reason why the incidence of mastitis has not decreased.

We have no data describing the extent to which recommended preventive measures are being implemented in practice, although such information is absolutely necessary if advisory services, and thus the udder health of dairy cows, are to be improved. Hence, the aim of the present study was to investigate which preventive measures are implemented in Swedish dairy herds with different housing and milking systems.

\section{MATERIALS AND METHODS}

\section{Herd Selection}

Data on preventive measures being applied were collected via a questionnaire survey. Herds enrolled in SOMRS and with at least 50 cows were eligible for inclusion (in 2010, $84 \%$ of all Swedish cows were included in SOMRS; Swedish Dairy Association, 2011). The limitation to herds with at least 50 cows excluded about half of all herds in SOMRS, corresponding to $25 \%$ of the cows (Swedish Dairy Association, 2011), but was introduced to make results more applicable for the future because smaller herds are rapidly decreasing in numbers. All herds with freestalls and an automatic milking system (AMS; $\mathrm{n}=298$ ) were included in the study, and samples of 300 herds with tiestalls and pipeline milking, and 300 herds with freestalls and parlor milking were identified by randomization.

\section{Survey Administration}

A self-administered postal questionnaire managed by Statistics Sweden (Statistiska centralbyrån, Örebro, Sweden; www.scb.se) was sent to participating herds in May 2011. Before being dispatched, the questionnaire was tested on 2 researchers, one with a background in questionnaire design and the other with experience in mastitis research. Statistics Sweden checked the formulation of the questions for clarity. The questionnaire was distributed together with written instructions, an explanation of the aim of the survey, contact information, and a lottery ticket. The person responsible for udder health in the herd was asked to answer the questions. Reminders were sent after $3 \mathrm{wk}$. The returned questionnaires were scanned electronically and proofread to check for incorrect entries and scanning mistakes.

\section{Questionnaire Design}

The questionnaire elicited information on the herd (e.g., housing system for milking cows, milking system, average herd size, production policy, the identity of persons working with the cows, and number of employees), the person responsible for udder health (e.g., sex, age, education, proportion of household's disposable income from milk production, and years responsible for udder health in the herd), and more specific questions regarding udder health and mastitis management [e.g., perceived frequency of acute clinical mastitis during 2010, perceived average bulk tank SCC (BTSCC) during 2010, most common mastitis pathogens, inclusion in udder health program, used sources of advice on udder health issues, and applied preventive measures]. The question on applied preventive measures was formulated as "Which of the following measures are implemented in the herd?" This was followed by 22 preventive measures related to stall hygiene, milking hygiene and milking routines, dry-cow management, and general management routines. The questionnaire also contained an open question inviting respondents to elaborate on their answers to specific questions or comment on the questionnaire itself. The questionnaire, in Swedish, is available from the first author on request.

\section{Data Editing}

The housing and milking systems reported in the questionnaire were combined into a new variable - herd type - with the main categories tiestalls and pipeline milking, freestalls and parlor milking, and freestalls and AMS. In all, 36 herds fell outside these categories, because they lacked information on either the housing system or the milking system, or both $(\mathrm{n}=3)$, or because multiple systems were reported $(\mathrm{n}=33)$. Herds of the first type were assumed to have the housing and milking systems reported in SOMRS. Five herds of the second type stated that they had tiestalls and pipeline milking in combination with a deep litter system (deep straw bedding). It was assumed these respondents had not noticed that the question concerned cows in milk and that the deep litter system was used for dry cows. Thus, these herds were coded as tiestalls with pipeline milking. Combinations of systems operated in 28 herds; namely, freestalls, AMS, and other systems (tiestalls, pipeline milking, or parlor milking; $\mathrm{n}=22$ ) and tiestalls, freestalls, and pipeline or parlor milking $(\mathrm{n}=$ 6 ). These herds were of no interest given the research question asked, so they were not analyzed further.

The housing and milking systems reported in the questionnaires were cross-checked against the housing and milking systems registered in SOMRS. Where inconsistencies were found, the information reported in the questionnaire was assumed to be correct (e.g., 6 herds were registered as having tiestalls and pipeline milking in SOMRS but reported as having freestalls 
Table 1. Comparison of the 428 participating herds and 470 nonresponders with respect to key performance indicators (at 10th, 50th, and 90 th percentiles) in the Swedish official milk-recording system ${ }^{1}$

\begin{tabular}{|c|c|c|c|c|c|c|c|}
\hline Performance indicator & \multicolumn{3}{|c|}{ Participating herds } & \multicolumn{3}{|c|}{ Nonresponders } & $P$-value \\
\hline Herd size (no.) & 55 & 80 & 189 & 56 & 82 & 161 & 0.64 \\
\hline Incidence of veterinary-treated mastitis (\%) & 0.9 & 11.4 & 26.7 & 0.9 & 10.3 & 28.1 & 0.93 \\
\hline Bulk-tank SCC ${ }^{2}$ & 167 & 244 & 349 & 167 & 254 & 373 & 0.06 \\
\hline
\end{tabular}

${ }^{1}$ All herds received a postal questionnaire requesting information related to mastitis management in Swedish dairy herds. A total of 898 questionnaires were distributed to 300 herds with tiestalls and pipeline milking, 300 herds with freestalls and parlor milking, and 298 herds with freestalls and an automatic milking system.

${ }^{2}$ Calculated bulk-tank SCC; that is, weighted arithmetic mean.

and parlor milking in the questionnaire). Herds that did not report average herd size in the questionnaire $(\mathrm{n}=4)$ were assigned the average herd size registered in SOMRS. All variables in the data set were checked manually for validity, and spurious values were crosschecked against the questionnaires.

\section{Statistical Tests}

We used SAS software (version 9.2; SAS Institute Inc., Cary, NC) to produce descriptive statistics and perform statistical analyses. $P$-values $\leq 0.05$ were considered statistically significant and $P$-values $>0.05$ and $\leq 0.10$ were considered tendencies.

External Validity. The possibility of selection bias was investigated by comparing participating herds with negative responders in respect to key performance indicators. For all herds, data on herd size, herd-average milk yield per cow, incidence of veterinary-treated mastitis, and BTSCC from 2010 (the year to which the questions in the questionnaire applied) were obtained from SOMRS, and the Wilcoxon rank-sum test was used to compare responders with nonresponders.

Differences Between Variables. For continuous variables (i.e., herd size, age of respondent, and time period during which the respondent had been responsible for udder health), the nonparametric Kruskal-Wallis test was used to analyze differences between herd types. For categorical variables, differences between variables were analyzed using Fisher's exact test.

\section{RESULTS}

\section{Response Rate and External Validity}

A total of 898 questionnaires were distributed. Four respondents declined to participate in the survey, 466 were not heard from, and 4 returned blank questionnaires. Accordingly, 428 usable questionnaires were obtained: an overall response rate of $48 \%$. We found no differences between participating herds and non- responders in terms of herd size, annual milk yield per cow, incidence of veterinary-treated mastitis, or BTSCC (Table 1).

\section{Description of Herds and Respondents}

The distribution of housing and milking systems in participating herds is given in Table 2. The 28 herds with a combination of systems were not further analyzed. The response rate in different herd types was $39 \%$ in herds with tiestalls and pipeline milking, $49 \%$ in herds with freestalls and parlor milking, and $45 \%$ in herds with freestalls and AMS.

Herd size differed between herd types $(P<0.001)$. Tiestall herds were smaller than freestall herds, and freestall herds with a milking parlor were larger than AMS herds (Figure 1). The proportion of herds applying an organic production policy was higher in freestall herds (Table 3). The proportion of respondents stating that they obtained more than $75 \%$ of the household's disposable income from milk production was higher in AMS herds $(65.2 \%$ compared with $51.7 \%$ in tiestall herds and $50.0 \%$ in herds with freestalls and milking parlors; $P=0.039$ and $P=0.014$, respectively). Most of the tiestall herds were run as family enterprises. Employees were most commonly used in herds with freestalls and milking parlors, and generally higher numbers of employees were used with this type of herd.

Table 2. Distribution of housing and milking systems in the 428 participating herds

\begin{tabular}{lc}
\hline Herd type & No. of herds (\%) \\
\hline Tiestalls/pipeline & $118(27.6)$ \\
Freestalls/parlor & $147(34.4)$ \\
Freestalls/AMS & $135(31.5)$ \\
Combination of systems & $28(6.5)$ \\
\hline
\end{tabular}

${ }^{1}$ All herds received a postal questionnaire requesting information related to mastitis management in Swedish dairy herds. A total of 898 questionnaires were distributed to 300 herds with tiestalls and pipeline milking, 300 herds with freestalls and parlor milking, and 298 herds with freestalls and an automatic milking system (AMS). 


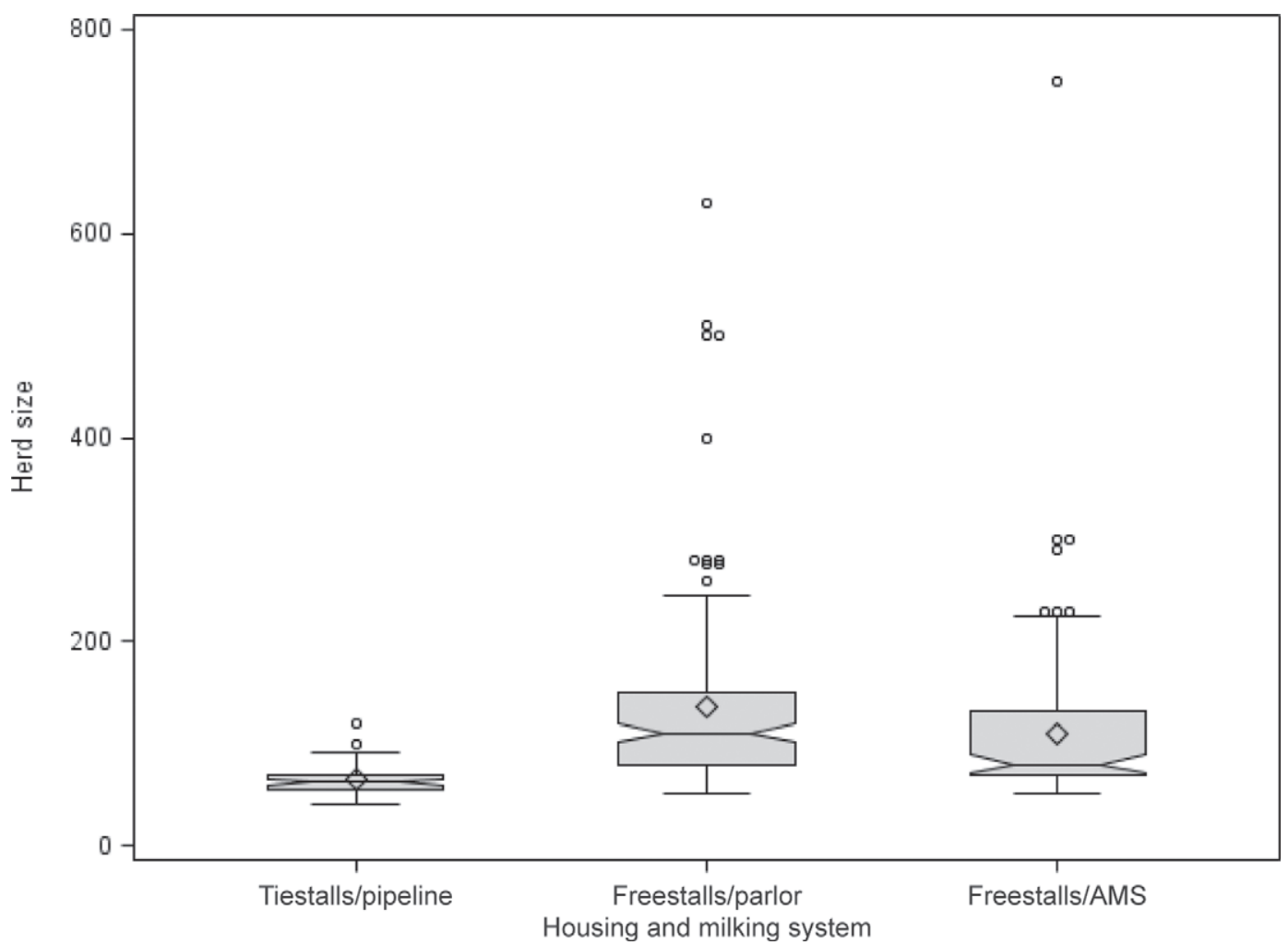

Figure 1. Notched boxplots showing the average herd size of the 400 participating herds with housing and milking systems of interest. The herds received a postal questionnaire requesting information related to mastitis management in Swedish dairy herds. A total of 898 questionnaires were distributed to 300 herds with tiestalls and pipeline milking, 300 herds with freestalls and parlor milking, and 298 herds with freestalls and an automatic milking system (AMS). Whiskers indicate the highest and lowest nonoutlier values; notches indicate medians; diamonds indicate means; and individual data points indicate outliers.

Most of the people responsible for udder health in the herds were male (Table 4). However, the proportion of females was higher in AMS herds. The respondents' level of education was lower in tiestall herds. The proportion of respondents with a university degree was higher in freestall herds with milking parlors than it was in herds with tiestalls, and tended to be higher in AMS herds compared with herds with tiestalls. The age of respondents did not differ across herd types $(P=0.18$; overall mean $=48.8 \mathrm{yr}, \mathrm{SD}=10.5 \mathrm{yr}$ ), but the period of time for which the respondent had been responsible for the udder health in the herd was shorter in freestall herds with milking parlors than in tiestall herds (mean $=16.6 \mathrm{yr}, \mathrm{SD}=12.3 \mathrm{yr}$ compared with mean $=20.8 \mathrm{yr}$, $\mathrm{SD}=11.3 \mathrm{yr} ; P=0.008)$. In AMS herds, respondents had been responsible for udder health for, on average, $18.6 \mathrm{yr}(\mathrm{SD}=11.9 \mathrm{yr})$.

\section{Udder Health Status}

Primary Pathogens. Irrespective of herd type, a substantial proportion of respondents did not know which pathogen caused most cases of mastitis in their herd (Table 5). Staphylococcus aureus and other Streptococcus and Enterococcus species were most commonly reported as the primary mastitis-causing pathogens. Staphylococcus aureus was reported as the primary mastitis-causing pathogen more often in tiestall herds than in AMS herds. A higher proportion of AMS herds reported Streptococcus agalactiae as the primary mastitis-causing pathogen.

Perceived Udder Health. The majority of respondents perceived the frequency of acute clinical mastitis and BTSCC in their herd as being at an average level (Table 6). Very few respondents reported the frequency of udder health problems as being very high. Respondents from AMS herds may have perceived the BTSCC as higher than respondents from other herd types did, but they also more often seemed to perceive the frequency of acute clinical mastitis as very low.

\section{Mastitis Control}

The most trusted source of information on udder health issues was the veterinarian, followed by advisors and the trade press (Table 7 ). Those responsible for ud- 
Table 3. Characteristics of the 400 participating herds with housing and milking systems of interest ${ }^{1}$

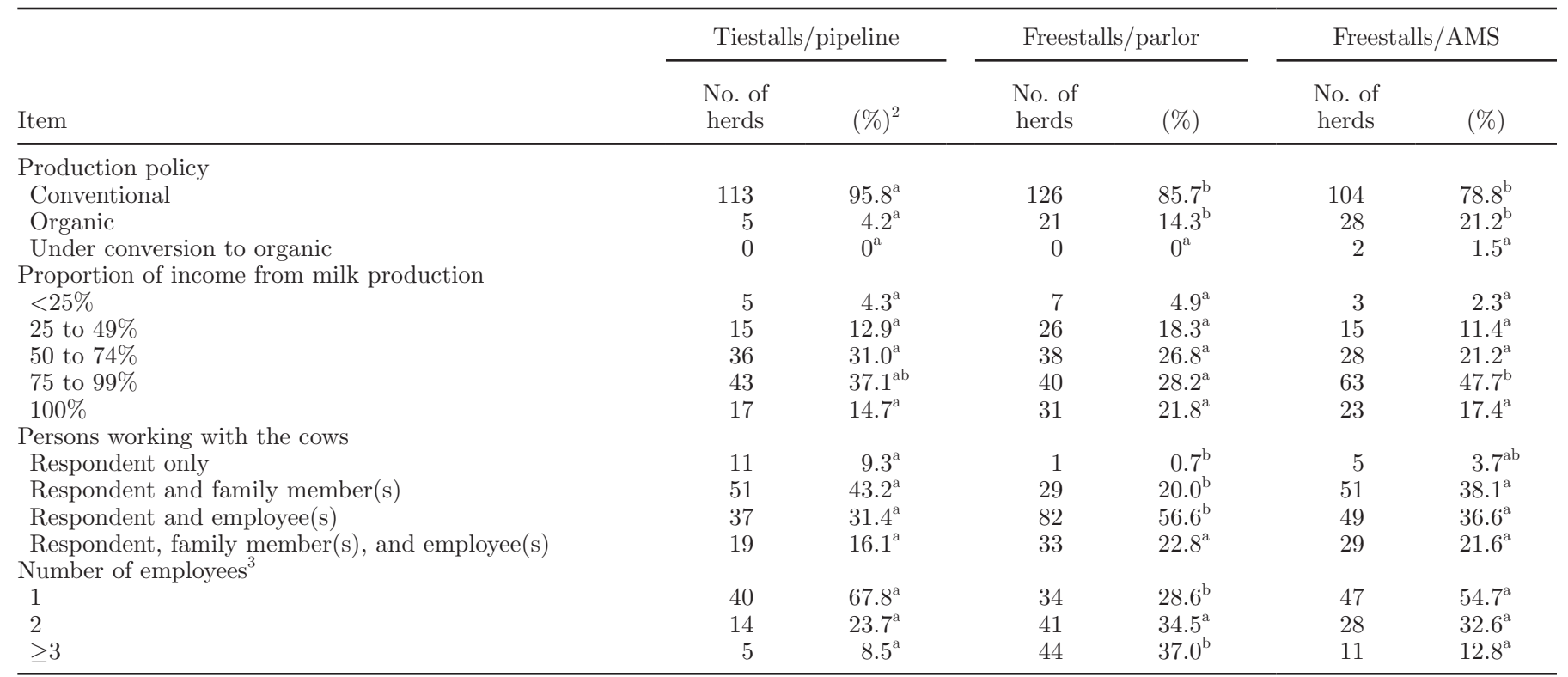

$\overline{\mathrm{a}}^{\mathrm{b}}$ Different superscripts within rows indicate significant differences at $P \leq 0.05$.

${ }^{1}$ All herds received a postal questionnaire requesting information related to mastitis management in Swedish dairy herds. A total of 898 questionnaires were distributed to 300 herds with tiestalls and pipeline milking, 300 herds with freestalls and parlor milking, and 298 herds with freestalls and an automatic milking system (AMS).

${ }^{2}$ For each level within variable, totals not summing to 100 are due to rounding.

${ }^{3}$ Not including family members.

der health in herds with freestalls and milking parlors consulted their employees on udder health issues more often than did respondents in the other herd types.

The proportion of herds enrolled in an udder health program administered by the Swedish Dairy Association or other organization was higher in herds with freestalls and milking parlors $(\mathrm{n}=58 ; 40.0 \%)$ than in tiestall herds $(\mathrm{n}=29 ; 25.2 \% ; P=0.013)$ and tended to be higher than the proportion of enrolled AMS herds (n $=38 ; 28.8 \% ; P=0.058)$.

Table 8 shows the preventive measures implemented in different types of herd. A substantial proportion of respondents ignored the udder health status of lactating cows when grouping them. Few herds grouped dry cows according to udder health status. Tiestall herds tended to do so more often than freestall herds, al-

Table 4. Sex and education of the 400 respondents from herds with housing and milking systems of interest ${ }^{1}$

\begin{tabular}{|c|c|c|c|c|c|c|}
\hline Item & \multicolumn{2}{|c|}{ Tiestalls/pipeline } & \multicolumn{2}{|c|}{ Freestalls/parlor } & \multicolumn{2}{|c|}{ Freestalls/AMS } \\
\hline Male & 87 & $74.4^{\mathrm{a}}$ & 108 & $74.5^{\mathrm{a}}$ & 77 & $58.3^{\mathrm{b}}$ \\
\hline Female & 30 & $25.6^{\mathrm{a}}$ & 37 & $25.5^{\mathrm{a}}$ & 55 & $41.7^{\mathrm{b}}$ \\
\hline \multicolumn{7}{|c|}{ Level of education } \\
\hline \multicolumn{7}{|c|}{ Agricultural education } \\
\hline Yes & 66 & $55.9^{\mathrm{a}}$ & 88 & $59.9^{\mathrm{a}}$ & 82 & $60.7^{\mathrm{a}}$ \\
\hline
\end{tabular}

${ }^{\mathrm{a}, \mathrm{b}}$ Different superscripts within row indicate significant differences at $P \leq 0.05$.

${ }^{1}$ All herds received a postal questionnaire requesting information related to mastitis management in Swedish dairy herds. A total of 898 questionnaires were distributed to 300 herds with tiestalls and pipeline milking, 300 herds with freestalls and parlor milking, and 298 herds with freestalls and an automatic milking system (AMS).

${ }^{2}$ For levels within variable, totals not summing to 100 are due to rounding. 
Table 5. Proportion of the 400 respondents from herds with housing and milking systems of interest referring to each pathogen as the primary mastitis-causing pathogen in their herd ${ }^{1}$

\begin{tabular}{|c|c|c|c|c|c|c|}
\hline \multirow[b]{2}{*}{ Species } & \multicolumn{2}{|c|}{ Tiestalls/pipeline } & \multicolumn{2}{|c|}{ Freestalls/parlor } & \multicolumn{2}{|c|}{ Freestalls/AMS } \\
\hline & $\begin{array}{l}\text { No. of } \\
\text { herds }\end{array}$ & $(\%)$ & $\begin{array}{l}\text { No. of } \\
\text { herds }\end{array}$ & $(\%)$ & $\begin{array}{l}\text { No. of } \\
\text { herds }\end{array}$ & $(\%)$ \\
\hline Streptococcus agalactiae & 1 & $0.9^{\mathrm{a}}$ & 3 & $2.0^{\mathrm{a}}$ & 10 & $7.4^{\mathrm{b}}$ \\
\hline Streptococcus dysgalactiae & 4 & $3.4^{\mathrm{a}}$ & 8 & $5.4^{\mathrm{a}}$ & 9 & $6.7^{\mathrm{a}}$ \\
\hline Escherichia coli & 2 & $1.7^{\mathrm{a}}$ & 8 & $5.4^{\mathrm{a}}$ & 7 & $5.2^{\mathrm{a}}$ \\
\hline Other streptococcus and enterococcus species & 25 & $21.2^{\mathrm{a}}$ & 21 & $14.3^{\mathrm{a}}$ & 19 & $14.1^{\mathrm{a}}$ \\
\hline Other coliform bacteria & 1 & $0.9^{\mathrm{a}}$ & 4 & $2.7^{\mathrm{a}}$ & 5 & $3.7^{\mathrm{a}}$ \\
\hline CNS & 4 & $3.4^{\mathrm{a}}$ & 12 & $8.2^{\mathrm{a}}$ & 13 & $9.6^{\mathrm{a}}$ \\
\hline Arcanobacterium pyogenes & 0 & $0^{\mathrm{a}}$ & 1 & $0.7^{\mathrm{a}}$ & 0 & $0^{\mathrm{a}}$ \\
\hline Don't know & 27 & $22.9^{\mathrm{a}}$ & 41 & $27.9^{\mathrm{a}}$ & 36 & $26.7^{\mathrm{a}}$ \\
\hline
\end{tabular}

${ }_{\mathrm{a}, \mathrm{b}}$ Different superscripts within row indicate significant differences at $P \leq 0.05$.

${ }^{1}$ All herds received a postal questionnaire requesting information related to mastitis management in Swedish dairy herds. A total of 898 questionnaires were distributed to 300 herds with tiestalls and pipeline milking, 300 herds with freestalls and parlor milking, and 298 herds with freestalls and an automatic milking system (AMS).

though this was only significant when compared with AMS herds.

Freestall herds with milking parlors implemented preventive measures connected with milking hygiene and milking routines to a greater extent than tiestall herds: milkers' gloves were more frequently worn, dirty udders were washed more often with water and allowed to dry before attaching the cluster, prestripping of all cows was performed more often, hard-milking cows were more often stimulated manually during milking, all cows were more often treated with a postmilking teat disinfectant, and clusters were more often rinsed with warm water after cows with acute clinical mastitis or high SCC had been milked.
A milking order based on udder health status was frequently applied in tiestall herds. However, two-thirds of the herds with freestalls and milking parlors and almost all of the AMS herds ignored the udder health status of the cows during milkings. The proportion of herds in which cows were kept standing for at least 30 min after milking was low and did not differ between herd types.

Slightly more than two-thirds of the herds administered dry-cow therapy in consultation with veterinarian, and in this respect we observed no differences between herd types. Few respondents regularly discussed the udder health status of the herd with a veterinarian, and the proportion that did do so was lower in tiestall

Table 6. Udder health status in different herd types during 2010, as perceived by the 400 respondents from herds with housing and milking systems of interest ${ }^{1}$

\begin{tabular}{|c|c|c|c|c|c|c|}
\hline Item & \multicolumn{2}{|c|}{ Tiestalls/pipeline } & \multicolumn{2}{|c|}{ Freestalls/parlor } & \multicolumn{2}{|c|}{ Freestalls/AMS } \\
\hline \multicolumn{7}{|c|}{ Frequency of acute clinical mastitis } \\
\hline Very high & 0 & $0^{\mathrm{a}}$ & 0 & $0^{\mathrm{a}}$ & 1 & $0.7^{\mathrm{a}}$ \\
\hline High & 6 & $5.1^{\mathrm{a}}$ & 15 & $10.3^{\mathrm{a}}$ & 13 & $9.6^{\mathrm{a}}$ \\
\hline Medium & 59 & $50.4^{\mathrm{a}}$ & 62 & $42.5^{\mathrm{a}}$ & 57 & $42.2^{\mathrm{a}}$ \\
\hline \multicolumn{7}{|c|}{ Average bulk-tank SCC } \\
\hline Very high & 1 & $0.9^{\mathrm{ab}}$ & 0 & $0^{\mathrm{a}}$ & 4 & $3.0^{\mathrm{b}}$ \\
\hline High & 19 & $16.2^{\mathrm{ab}}$ & 15 & $10.3^{\mathrm{a}}$ & 28 & $21.2^{\mathrm{b}}$ \\
\hline Medium & 60 & $51.3^{\mathrm{a}}$ & 70 & $48.0^{\mathrm{a}}$ & 79 & $59.9^{\mathrm{a}}$ \\
\hline Low & 34 & $29.1^{\mathrm{a}}$ & 49 & $33.6^{\mathrm{a}}$ & 21 & $15.9^{\mathrm{b}}$ \\
\hline Very low & 3 & $2.6^{\mathrm{ab}}$ & 12 & $8.2^{\mathrm{a}}$ & 0 & $0^{\mathrm{b}}$ \\
\hline
\end{tabular}

${ }^{\mathrm{a}, \mathrm{b}}$ Different superscripts within row indicate significant differences at $P \leq 0.05$.

${ }^{1}$ All herds received a postal questionnaire requesting information related to mastitis management in Swedish dairy herds. A total of 898 questionnaires were distributed to 300 herds with tiestalls and pipeline milking, 300 herds with freestalls and parlor milking, and 298 herds with freestalls and an automatic milking system (AMS).

${ }^{2}$ For each level within variable, totals not summing to 100 are due to rounding. 
Table 7. Information channels used by the 400 respondents from herds with housing and milking systems of interest to obtain advice on udder health issues ${ }^{1}$

\begin{tabular}{|c|c|c|c|c|c|c|}
\hline Item & \multicolumn{2}{|c|}{ Tiestalls/pipeline } & \multicolumn{2}{|c|}{ Freestalls/parlor } & \multicolumn{2}{|c|}{ Freestalls/AMS } \\
\hline Advisor & 67 & $56.8^{\mathrm{a}}$ & 75 & $51.0^{\mathrm{a}}$ & 61 & $45.2^{\mathrm{a}}$ \\
\hline Other milk producers & 23 & $19.5^{\mathrm{a}}$ & 22 & $15.0^{\mathrm{a}}$ & 29 & $21.5^{\mathrm{a}}$ \\
\hline Employees & 8 & $6.8^{\mathrm{a}}$ & 28 & $19.1^{\mathrm{b}}$ & 14 & $10.4^{\mathrm{a}}$ \\
\hline Internet & 6 & $5.1^{\mathrm{a}}$ & 14 & $9.5^{\mathrm{a}}$ & 14 & $10.4^{\mathrm{a}}$ \\
\hline Courses & 11 & $9.3^{\mathrm{a}}$ & 25 & $17.0^{\mathrm{a}}$ & 22 & $16.3^{\mathrm{a}}$ \\
\hline Other $^{2}$ & 1 & $0.9^{\mathrm{a}}$ & 2 & $1.4^{\mathrm{a}}$ & 4 & $3.0^{\mathrm{a}}$ \\
\hline
\end{tabular}

${ }^{\mathrm{a}, \mathrm{b}}$ Different superscripts within row indicate significant differences at $P \leq 0.05$.

${ }^{1}$ All herds received a postal questionnaire requesting information related to mastitis management in Swedish dairy herds. A total of 898 questionnaires were distributed to 300 herds with tiestalls and pipeline milking, 300 herds with freestalls and parlor milking, and 298 herds with freestalls and an automatic milking system (AMS).

${ }^{2}$ Other specified as own experience $(\mathrm{n}=4 ; 2$ respondents were veterinarians), business partner $(\mathrm{n}=1)$, AMS personnel at DeLaval International $(\mathrm{n}=1)$, or not specified $(\mathrm{n}=2)$.

herds than it was in other herd types. Respondents with herds enrolled in an udder health program more often had regular discussions with a veterinarian regarding the udder health status of the herd compared with respondents with herds that were not enrolled in any program (69.6 and $16.9 \%$, respectively; $P=0.001$ ). Among herds not enrolled in an udder health program, the proportion of respondents with AMS herds who discussed the udder health of the herd with a veterinarian on a regular basis was larger than the proportion of respondents with tiestall herds who did likewise (22.3 and $9.3 \%$, respectively; $P=0.025$ ).

The vast majority of tiestall herds did not allow cows and heifers to calve in single pens that were cleaned between animal occupations. The proportion of herds in which cows and heifers were allowed to calve in single pens that were cleaned between animal occupations was higher in freestall herds, but still a large proportion of these herds did not follow this practice.

Almost all herds replaced teat-cup liners according to the manufacturer's recommendations. Irrespective of herd type, someone on the staff continually reviewed the feeding plans and revised them as needed. Most herds fed dry cows a mineral feed that covered their needs, but herds with freestalls and milking parlors did this more often than tiestall herds. Herds with freestalls and milking parlors also tended to do this more often than AMS herds.

\section{DISCUSSION}

\section{Implementation of Preventive Measures}

Stall Hygiene. Stalls were cleaned and fresh bedding material was provided more frequently in tiestall herds than in freestall herds, which might suggest better stall hygiene in the former. The result might, however, also indicate that tiestall herds had to clean stalls and provide fresh bedding more often to reach the same level of stall hygiene as freestall herds.

Grouping and separation of cows according to udder health status is stressed by the Swedish Dairy Association as an important means of reducing the risk of contagious mastitis (Persson, 2010). Despite this, a substantial proportion of respondents ignored the udder health of their lactating cows when grouping them. Grouping and separation differed between herd types, probably reflecting the ease with which the grouping of cows can be performed within each system. The freestall herds with milking parlors were larger than the AMS herds and might, therefore, have been more suited to division into reasonably large subgroups according to udder health status. Furthermore, grouping of lactating cows in AMS herds is hampered by the need to maintain a sufficiently large group size per unit.

Milking Hygiene and Milking Routines. Some of the preventive measures related to milking routines and milking hygiene were not applicable in AMS herds. Therefore, the low frequency with which these were implemented in AMS herds does not indicate that the herds did not invest in mastitis control. Rather, AMS herds reporting the implementation of such measures were most certainly incorrect entries.

Tiestall herds put less effort into preventing mastitis during milking than freestall herds with milking parlors. This is likely explained by practical matters. For example, udder preparation might be hampered by the difficulty of providing access to disposable paper towels and running water. Furthermore, teat disinfectants 
Table 8. Implemented preventive measures in the 400 participating herds with housing and milking systems of interest ${ }^{1}$



\begin{tabular}{|c|c|c|c|c|c|c|}
\hline \multirow[b]{2}{*}{ Item } & \multicolumn{2}{|c|}{ Tiestalls/pipeline } & \multicolumn{2}{|c|}{ Freestalls/parlor } & \multicolumn{2}{|c|}{ Freestalls/AMS } \\
\hline & $\begin{array}{l}\text { No. of } \\
\text { respondents }\end{array}$ & $(\%)$ & $\begin{array}{l}\text { No. of } \\
\text { respondents }\end{array}$ & $(\%)$ & $\begin{array}{l}\text { No. of } \\
\text { respondents }\end{array}$ & $(\%)$ \\
\hline Stalls cleaned and fresh bedding material provided $\geq 2$ times daily & 118 & $100.0^{\mathrm{a}}$ & 130 & $88.4^{\mathrm{b}}$ & 113 & $83.7^{\mathrm{b}}$ \\
\hline Yards cleaned $\geq 2$ times daily & 36 & $30.5^{\mathrm{a}}$ & 93 & $63.3^{\mathrm{b}}$ & 91 & $67.4^{\mathrm{b}}$ \\
\hline Cows in milk grouped according to udder health status & 83 & $70.3^{\mathrm{a}}$ & 51 & $34.7^{\mathrm{b}}$ & 9 & $6.7^{\mathrm{c}}$ \\
\hline Dirty udders washed with water and dried before attaching the cluster & 34 & $28.8^{\mathrm{a}}$ & 71 & $48.3^{\mathrm{b}}$ & 13 & $9.6^{\mathrm{c}}$ \\
\hline Teats cleaned before attaching the cluster, one cloth per cow & 107 & $90.7^{\mathrm{a}}$ & 129 & $87.8^{\mathrm{a}}$ & 6 & $4.4^{\mathrm{b}}$ \\
\hline All cows prestripped & 82 & $69.5^{\mathrm{a}}$ & 126 & $85.7^{\mathrm{b}}$ & 75 & $55.6^{\mathrm{c}}$ \\
\hline Hard-milking cows stimulated manually during milking & 34 & $28.8^{\mathrm{a}}$ & 62 & $42.2^{\mathrm{b}}$ & 8 & $5.9^{\mathrm{c}}$ \\
\hline All cows treated with postmilking teat disinfectant & 88 & $74.6^{\mathrm{a}}$ & 126 & $85.7^{\mathrm{b}}$ & 105 & $77.8^{\mathrm{ab}}$ \\
\hline Clusters rinsed with warm water after milking cows with $\mathrm{CM}^{2}$ & 31 & $26.3^{\mathrm{a}}$ & 86 & $58.5^{\mathrm{b}}$ & 76 & $56.3^{\mathrm{b}}$ \\
\hline Clusters rinsed with warm water after milking cows with high SCC & 19 & $16.1^{\mathrm{a}}$ & 56 & $38.1^{\mathrm{b}}$ & 53 & $39.3^{\mathrm{b}}$ \\
\hline Cows with CM milked last & 94 & $79.7^{\mathrm{a}}$ & 58 & $39.5^{\mathrm{b}}$ & 8 & $5.9^{\mathrm{c}}$ \\
\hline Cows with high SCC milked last & 102 & $86.4^{\mathrm{a}}$ & 48 & $32.7^{\mathrm{b}}$ & 2 & $1.5^{\mathrm{c}}$ \\
\hline Cows kept standing for $\geq 30$ min after milking & 12 & $10.2^{\mathrm{a}}$ & 24 & $16.3^{\mathrm{a}}$ & 18 & $13.3^{\mathrm{a}}$ \\
\hline Teat-cup liners replaced according to manufacturer's recommendations & 107 & $90.7^{\mathrm{a}}$ & 136 & $92.5^{\mathrm{a}}$ & 127 & $94.1^{\mathrm{a}}$ \\
\hline Dry-cow therapy administered in consultation with veterinarian & 85 & $72.0^{\mathrm{a}}$ & 100 & $68.0^{\mathrm{a}}$ & 97 & $71.9^{\mathrm{a}}$ \\
\hline Dry cows fed a mineral feed that covers their needs & 82 & $69.5^{\mathrm{a}}$ & 118 & $80.3^{\mathrm{b}}$ & 95 & $70.4^{\mathrm{ab}}$ \\
\hline Dry cows grouped according to udder health status & 14 & $11.9^{\mathrm{a}}$ & 11 & $7.5^{\mathrm{ab}}$ & 3 & $2.2^{\mathrm{b}}$ \\
\hline Calvings in single pens cleaned between animal occupations & 32 & $27.1^{\mathrm{a}}$ & 80 & $54.4^{\mathrm{b}}$ & 89 & $65.9^{\mathrm{b}}$ \\
\hline Udder health status of the herd regularly discussed with veterinarian & 26 & $22.0^{\mathrm{a}}$ & 56 & $38.1^{\mathrm{b}}$ & 52 & $38.5^{\mathrm{b}}$ \\
\hline Feeding plans continuously reviewed and revised when needed & 98 & $83.1^{\mathrm{a}}$ & 130 & $88.4^{\mathrm{a}}$ & 117 & $86.7^{\mathrm{a}}$ \\
\hline
\end{tabular}

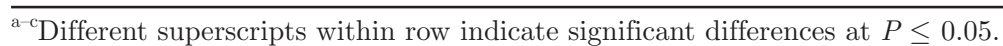

${ }^{1}$ All herds received a postal questionnaire requesting information related to mastitis management in Swedish dairy herds. A total of 898 questionnaires were distributed to 300 herds with tiestalls and pipeline milking, 300 herds with freestalls and parlor milking, and 298 herds with freestalls and an automatic milking system (AMS).

${ }^{2} \mathrm{CM}=$ acute clinical mastitis. 
must be carried around, which may discourage routine use. However, the lower proportion of tiestall herds washing dirty udders before attaching the cluster might reflect cleaner udders as a consequence of better stall hygiene. Nevertheless, the results indicate that advisors should emphasize the importance of preventive measures related to milking routines and milking hygiene even more strenuously to farmers with tiestall herds.

Most of the tiestall herds implemented a milking order in which cows with acute clinical mastitis and cows with high SCC were milked last. In contrast, few freestalls with milking parlors considered the udder health status of the cows during milkings. This is a serious issue, because strictly adhering to a set milking order and cow-grouping according to udder health status are crucial steps in limiting the spread of contagious pathogens (Persson, 2010). A strict order of cows being milked is, however, difficult to achieve in freestall herds. Still, the udder health status of cows should be considered during milkings in freestall herds with milking parlors; for example, by proper grouping of lactating cows and by always milking mastitic cows and cows with high SCC last. The latter was only practiced in about one-third of freestall herds with milking parlors. Thus, advisors must convey the importance of considering the udder health status of the cows during milkings to farmers with freestall herds and milking parlors.

Irrespective of herd type, very few respondents reported that their cows were kept standing for at least 30 min after milking. Preventing cows from lying down after milking is usually done by providing feed, but this involves an extra step in the milking process. It has been shown that farmers prefer monetary investment in mastitis control over investments requiring added labor or changes in routine (Huijps et al., 2009). Our results here likely reflect this reluctance to take on additional work or alter routines.

Dry-Cow Management. The dry period is critical to udder health, offering the opportunity to eliminate existing infections as well as challenging cows with new infections. A surprisingly high proportion of herds did not take advantage of the opportunity to eliminate existing infections by administering dry-cow treatment in consultation with a veterinarian. This might indicate limited knowledge among the respondents of the consequences of not doing so. During the dry period, the mammary gland exhibits wide fluctuations in its susceptibility to infection, going through both its most resistant and its most susceptible phases (Bradley and Green, 2004). The transition from dry period to lactation is a particularly critical, because cows are more or less immunocompromised during this period (Pyörälä, 2008). Most new infections during the dry period are caused by environmental pathogens (Dingwell et al.,
2003; Pyörälä, 2008), and the importance of a clean environment in reducing the risk of mastitis has been demonstrated (Green et al., 2007; Piepers et al., 2011). To reduce the risk of new infections, it is recommended (Persson, 2010) that cows and heifers be allowed to calve in single pens that are cleaned between animal occupations. However, this advice was not followed in more than two-thirds of tiestall herds. Facilities of tiestall herds are usually older and often do not contain calving pens. Some of these herds were probably among those granted an exception from Swedish legislation stating that cows and heifers are not to be tied during calving, and a proportion of these herds probably continue to allow animals to calve in the tiestalls. Beginning August 1, 2012, Swedish animal welfare legislation stipulates that cows and heifers shall be allowed to calve freely, except in the case of dystocia or when the calving pen is already occupied (Swedish Board of Agriculture, 2010). Problems may arise from this discrepancy between legislation and common practice. The proportion of freestall herds not allowing cows and heifers to calve in single pens cleaned between animal occupations was surprisingly high, given that these herds generally have modern facilities and thus could reasonably have been expected to have planned for single calving pens.

Milk leakage may occur in dry cows that are overfed before calving, are in sight or sound of the milking equipment, are in the presence of calves, or have been dried off while they still have a high milk yield (Bradley and Green, 2004). Milk leakage may contribute to increased levels of contagious pathogens in the environment (Peeler et al., 2000). It would therefore be advantageous to group dry cows according to udder health status, but this happened in very few herds. The practice was less common in herds with freestalls and AMS than it was in herds with tiestalls, and, although it was not statistically significant, we observed a trend suggesting that the practice was less common in herds with freestall herds and milking parlors. These findings were somewhat unexpected, considering that freestall herds generally have more modern facilities. One might have thought that the process of planning and building a dairy facility would include a review of housing solutions that provide optimal conditions for improving and maintaining udder health, but our findings suggest this has not happened in the herds involved in the study. Taken together, the results emphasize the need for advisors and veterinarians to stress the importance of proper dry-cow management and a high level of calving hygiene to avoid new mastitis infections.

General Management Routines. The proportion of respondents stating that they regularly discussed the udder health status of the herd with a veterinarian was lower in tiestall herds, although the proportion of herds 
administering dry-cow treatment in consultation with a veterinarian was the same in all herd types. This might indicate a preference for treatment rather than prevention among respondents with tiestall herds.

Overall, the proportion of respondents stating that they regularly discussed the udder health status of the herd with a veterinarian was rather low, especially given that the veterinarian was the most important information channel for advice on udder health issues. Participation in an udder health program encouraged regular discussion with a veterinarian of the udder health status of the herd. Participation in an udder health program therefore appears to promote knowledge transfer.

Among herds not enrolled in an udder health program, a larger proportion of AMS herds than tiestall herds discussed the udder health of the herd with a veterinarian on a regular basis. These findings suggest that respondents from AMS herds not enrolled in udder health programs were more active in seeking advice on udder health issues than their tiestall herd counterparts. Perhaps as a result they were better able to maintain udder health at a reasonable level without enrolling in an udder health program compared with their tiestall herd counterparts. The reluctance of respondents with tiestall herds to discuss udder health with a veterinarian might be a consequence of them being less businessoriented; the tiestall herds in this study were smaller and more often run as family enterprises.

Most respondents reported that feeding plans were continuously reviewed and revised when necessary. This suggests that their awareness of the importance of feeding cows diets adjusted according to their current need was high.

An important tool in preventing mastitis is the culling of chronically infected cows, and culling decisions are among the most complex decisions a farmer has to make. In the present study, we decided that it would not be possible to formulate an unbiased question about culling related purely to udder health.

\section{Awareness of Primary Mastitis-Causing Pathogen}

Under Swedish legislation, antibiotic therapy cannot be initiated without a veterinarian making the diagnosis. At the time of mastitis diagnosis, a milk sample is retrieved and bacteriologically cultured (at the veterinary clinic or an accredited laboratory), according to the Swedish national guidelines for mastitis therapy (applied since 1995). Farmers should receive information about the results of milk cultures, but it is not known to what extent results are communicated back to the farm. However, farmers usually request information about the results of milk cultures and they do receive them, at least by telephone (H. Landin, Swedish Dairy Association, Stockholm, personal communication). In addition, farmers have a high degree of understanding of what this information means. Thus, it seemed reasonable to assume that the respondents in this study would know whether their primary mastitiscausing pathogen was of contagious or environmental origin, and also know the species to which the pathogen belonged. However, the results seemed to indicate otherwise.

\section{Study Design and External Validity}

The response rate was largely equal across herd types, and we found no differences between participating herds and negative responders in respect to the investigated key performance indicators. In other words, we found no evidence of selection bias. The fact that the questionnaire was self-administered might have introduced some bias in measurement validity. It is expected that farmers are aware of what they should be doing to prevent mastitis. Those involved in the present study also knew that their herds could be identified by us, and this might, consciously or subconsciously, have led them to overestimate their efforts in mastitis control.

\section{CONCLUSIONS}

Differences with respect to the preventive measures implemented in herds with different housing and milking systems were found. Tiestall herds implemented more preventive measures related to stall hygiene, whereas freestall herds with milking parlors implemented more preventive measures related to milking hygiene and milking routines. Lactating cows were rarely grouped according to udder health status in freestall herds and, irrespective of herd type, few respondents grouped dry cows according to udder health status. The majority of freestall herds with milking parlors and almost all of the AMS herds declined to implement a milking order based on udder health status. In a large proportion of herds, cows and heifers were not allowed to calve in single pens that were cleaned between animal occupations; this was particularly common in tiestall herds. These findings can be used by advisors to tailor advice specifically to different herd types and thus improve the efficiency of mastitis control and udder health in dairy cows.

\section{ACKNOWLEDGMENTS}

The authors gratefully acknowledge funding for this project from The Swedish Research Council Formas (Stockholm) and The Royal Swedish Academy of Agri- 
culture and Forestry (Stockholm). The authors thank Ylva Persson and Håkan Landin (udder health experts at the Swedish Dairy Association, Stockholm) for useful input on the structure of the questionnaire and on mastitis control in general.

\section{REFERENCES}

Bradley, A. J., and M. J. Green. 2004. The importance of the nonlactating period in the epidemiology of intramammary infection and strategies for prevention. Vet. Clin. North Am. Food Anim. Pract. 20:547-568.

Dingwell, R. T., D. F. Kelton, and K. E. Leslie. 2003. Management of the dry cow in control of peripartum disease and mastitis. Vet. Clin. North Am. Food Anim. Pract. 19:235-265.

Green, M. J., A. J. Bradley, G. F. Medley, and W. J. Browne. 2007. Cow, farm, and management factors during the dry period that determine the rate of clinical mastitis after calving. J. Dairy Sci. 90:3764-3776.

Heringstad, B., G. Klemetsdal, and J. Ruane. 2000. Selection for mastitis resistance in dairy cattle: A review with focus on the situation in the Nordic countries. Livest. Prod. Sci. 64:95-106.

Huijps, K., H. Hogeveen, T. J. G. M. Lam, and R. B. M. Huirne. 2009 Preferences of cost factors for mastitis management among Dutch dairy farmers using adaptive conjoint analysis. Prev. Vet. Med. 92:351-359.

Johansson, K., S. Eriksson, J. Pösö, M. Toivonen, U. Sander Nielsen, J.-Å. Eriksson, and G. Pedersen Aamand. 2006. Genetic evalu- ation of udder health traits for Denmark, Finland, and Sweden. Pages 92-96 in Proc. 2006 Interbull Mtg. Interbull Centre, Uppsala, Sweden.

Mörk, M., A. Lindberg, S. Alenius, I. Vågsholm, and A. Egenvall. 2009. Comparison between dairy cow disease incidence in data registered by farmers and in data from a disease-recording system based on veterinary reporting. Prev. Vet. Med. 88:298-307.

Peeler, E. J., M. J. Green, J. L. Fitzpatrick, K. L. Morgan, and L. E. Green. 2000. Risk factors associated with clinical mastitis in low somatic cell count British dairy herds. J. Dairy Sci. 83:2464-2472.

Persson, Y. 2010. Mastiter och celltal, FOKUS Mjölkkons välfärd och produktion. Swedish Dairy Association, Stockholm, Sweden.

Piepers, S., K. Peeters, G. Opsomer, H. W. Barkema, K. Frankena, and S. De Vliegher. 2011. Pathogen group specific risk factors at herd, heifer and quarter levels for intramammary infections in early lactating dairy heifers. Prev. Vet. Med. 99:91-101.

Pyörälä, S. 2008. Mastitis in post-partum dairy cows. Reprod. Domest. Anim. 43(Suppl. 2):252-259.

Swedish Board of Agriculture. 2010. Statens jordbruksverks föreskrifter och allmänna råd om djurhållning inom lantbruket m.m., S.JVFS 2010:15. Accessed Jun. 7, 2012. http://www.sjv.se/download/18.6 b0af7e81284865248a80002467/2010-015.pdf.

Swedish Dairy Association. 1991. Årsstatistik inkl djurhälsovård 1990/91. Swedish Dairy Association, Eskilstuna, Sweden.

Swedish Dairy Association. 2006. Djurhälsovård 2005/2006. Swedish Dairy Association, Stockholm, Sweden.

Swedish Dairy Association. 2011. Husdjursstatistik 2011. Swedish Dairy Association, Stockholm, Sweden. 